\title{
Construction of Social Support System of Family Education
}

\author{
Songtao Li \\ School of Education and Sports, Bohai University, Jinzhou, 121013, China \\ lisongtao2008@yeah.net
}

Keywords: family education; social support; system; construction

\begin{abstract}
Family education, is the starting point of person's education, and is an important part of the education system. In the period of social transformation, parents face unprecedented new problems, new challenges, and family education urgently needs more social support. Social support systems include government, school, society and network support, and there are still many problems. Based on the analysis of social support in family education, this paper constructs the social support system of family education, including improving the comprehensive benefit of government support in family education, perfecting the operation mechanism of school support, strengthening the support ability of social organization and constructing the three-dimensional network support system, aiming at promoting the whole society to pay attention and supporting family education, and solving the problems in family education.
\end{abstract}

\section{Introduction}

Family education, is the starting point of person's education, and is an important part of education system. Family education is related to the present and future of country, and the level of family education development has become a degree to measure the standard of social civilization[1]. At present, China is in the period of social transformation, the transformation of social structure and operation mechanism, the reconstruction of value system; the rapid development of new media era, the change of communication way, the situation of economic globalization, cultural integration and pluralistic development. All the things will be reflected in various forms in family life, and have an impact on family education. Contemporary parents face unprecedented new situations, new problems, new challenges, and family education urgently needs more social support[2]. Social transformation period, improving the social support system in family education, not only improving the quality of family education, but also promoting family and society harmony[3]. The construction of social support system in family education will promote the further development of family education and provide a better development platform for family education.

\section{The Function of Family Education Social Support}

Family education social support refers to the face of family education difficulties or demand, parents with individuals or organizations from social environment in the formation of the help relationship and the process of occurrence, in the results of parents or the family obtained the various help from family outside[4]. The function is as follows:

(1) Improve the quality of family education, and promote the growth of family. First, the family education social support spread the advanced concept of family education. During the period of social transformation, the concept of family education shows the diversified trend. On the one hand, people are eager to new family education concept to bring more effective family education effect; on the other hand, a lot of theory and ideas make the feel at a loss. Family education social support is the best place for government and social to broadcast family education knowledge and concept, with professional and objective features that can support parents or family education. Second, the family education social support promote family education practical skills. Family education specialists, mentors and enthusiasts who have family education experience can provide parents with the opportunity to train, guide and practice. Moreover, family education social support activities also provide parents with the opportunity to communicate with each other, and let family education 
social support to play a greater role.

(2) Improve the cooperation quality of family and school, and promote the application of research results. First, promote the cooperation between family and school. On the one hand, improve the level of family education to meet the expectations of school education on family education; on the other hand, promote the development of school education, and let schools and families to become more equal partners. Avoid school education to be in the status quo, in order to provide more open, democratic and high-quality school education for children and adolescents. Second, promote the application of family education research results. The existence of social support institutions for family education, provides a theoretical and practical approach for family education researchers, participate more in family education practice and communicate with the grassroots family education practitioners. More opportunities combine the theory of family education with the specific reality of our country to promote theoretical innovation and improve the level of family education.

(3) Strengthen the link of family and society, and improve the environment of children's growth. First, build the bridge between government and family communication. With the increasingly complete education system, our government has begun to integrate family education into the government education service system, parents and schools are increasingly valued is the embodiment of this trend. The establishment of schools for parents, not only provides effective means of support for the improvement of family education, but also provides new platform for effective communication between government and family. Second, rely on social support. Family education problems, involving every member in the society, a wide range of problems need to solve , only through social assistance can effectively solve the problem that individual family encountered family education. At the same time, with the accumulation of social wealth, many people are willing to improve the level of social education. Rely on the support of society, and develop family education.

\section{Analysis of the Current Situation of Family Education Social Support}

In the field of family education, the main body of social support exists in two forms, namely, organization and individual, organization can be divided into government organizations, social organizations and schools. With the popularity of Internet, individuals and organizations can use the network platform for family education social support. In order to fully describe the current situation of family education social support, this paper analyzes the current situation of social support in family education from four aspects: government organization, social organization, school and Internet.

(1) Analysis of the current situation of government organization support to family education. First, support content and pay attention to cognition. The social supports from government organization for the family education are focused on the cultivation of cognition and look down on practice. Libraries provide extracurricular reading, the community has the obligation to teach children classes, the Women's Federation makes lectures for children, the society has become a big classroom. Focus on cognition, lack of practical support content, so the impact of family education social support was affected. Second, the support form is partial to one-way teaching. Various lectures are the most outstanding performance of this form. Lectures in the dissemination of educational concept function is obvious, but for the specific guidance of family education is difficult to achieve expected results. This form of support is too monotonous, easily lead negative emotions to parents, hinder the development of family education. Finally, the number of social education places is insufficient. With the various types of museums, memorials and other places free of charge, people's cultural life space has been improved to certain extent. However, limited venues are still unable to meet the needs for family education activities.

(2) Analysis of the current situation of family education supporting in schools. School supports family education in the form of: parental school, parents' meeting, parent-school contact manual, information platform and home visit. School lacks human and financial resources to support family education. Although the relevant documents require school to shoulder the responsibility to support 
family education, but the reality of the situation, school lacks support of personnel, funds and other related resources for family education. From staff point of view, although school has a large number of educators, but they are familiar with the field of school education, family education is not good at. Family education and school education are two types of education, there are many differences in educational goals, content, methods and evaluation. Especially for the guidance of parents belonging to the scope of adult education, school teachers do not have this professional preparation. From financial point of view, support family education requires stable fund investment. At present, lack of school funds, which is difficult in the existing conditions to improve the quality of family education support, which led the school's family education guidance work not carried out in depth, and can not get the expected results.

(3) Analysis of the current situation of social organization 's support to family education. Family education services guidance agency and other social organizations, lack of necessary access mechanisms and professional norms, family education guidance and service market is confused. Full-time family education staffs lack of professional quality is not enough. These problems seriously restrict the healthy development of family education[5]. In addition, China's social organization support family education mainly focus on the assistance of special groups. Many social organizations are large in scale, credible, and capable of concentrating their strength in a shorter time, in a broader context, with a greater effort and a more direct way to benefit the needs of the group. In the case of family education, their actions are of vital importance to special families, such as families in remote areas who are unable to get their children to school because of poverty, families who are poor and unable to complete their university education, education and technology for helping poor mothers and so on. These behaviors have a positive impact on family education, thereby enhancing the educational level of the children from these families and benefiting more children and adolescents. But the social organization also exists problems like organizational model and the operation mechanism which is imperfect.

(4) Analysis of the current situation of family education network support. New media technology has created a new and rich family education model. Family-school interaction, e-books and digital education platform, create extensive space for developing children's learning potential, also provide display platform for the family education institutions[6]. These unofficial institutions provide new ideas and perspectives for family education and meet the needs of the diverse family education. However, the Internet information sources are more complex, and even interfere the family education, so we need the norms of authority and effective identification of parents. The complexity of information source, on the one hand, shows that the cyberspace is more inclusive than the real space; on the other hand, it also exposes network as the existence of the virtual space with many problems. The information age, Internet is changing people's lives. One of the most notable situation is the digestion of authority, because the individual get more opportunities and platforms to speak, the door of publishing views reduced. Network does not have the traditional media strict audit mechanism, and varieties of information credibility and authority also reduce. Network information with good and bad things intermingled, this state for the spread of family education information has a strong negative impact, and urgently needs the professional institutions and authorities' intervention and guidance.

\section{The Construction of Social Support System of Family Education}

Combined with the above analysis, with reference to the relevant documents, the construction of social support system of family education is from the following four aspects:

(1) Improve the comprehensive benefits of government to support family education. First, improve the supply of resources to support society. People are the foundation of social development and the ultimate goal of social development. Family education has solid foundation role for individual growth and development, which can generally enhance the quality of people's level and also has promoting effect on the whole social development. Therefore, government should mobilize relevant resources, actively support family education, improve the educational environment in poor families, promote the good operation in parental schools and ensure the effective implementation in 
community family education program. Second, improve the support effect of legal policy. First, improve family education related to the legal system. Giving legal status for family education is an urgent need to ensure the importance of family education and promote overall coordinated development of the education system[5]. Second, perfect the family education social support policy system. Actively encourage social organizations, enterprises, public institutions and individuals to participate in family education social support activities. Finally, make effective family education social support regulatory policies, so that the powers and responsibilities from various departments are clear, so that the limited resources are fully utilized, so that the family really benefit from the government's social support. Third, improve the operational mechanism of social support. First, the head office of parental school is placed under educational department, and the Women's Federation and other organizations are required to assist and cooperate. Second, we need professional technology institute and government departments work together to cultivate more professionals, making family education guidance professional. Finally, curriculum provision, teacher qualification and project planning of parental school should be subject to professional audit.

(2) School plays an important role in family education[7]. First, strengthen school and family education work guidance. Kindergartens, primary and middle schools need to improve the family education work mechanism, coordinate parent committee, parental schools, parents' meeting, home visit, parents' open day and parents' reception day and other communication channels, teachers as the main body, experts, scholars and excellent parents participating together, combining the backbone of family education. Second, enrich the content of school guidance service. Hold parents ' training seminars and counseling services, carrying out advanced educational ideas and scientific education knowledge guidance; hold experience exchange meeting, and play a good family demonstration example. Organize social practice activities, regularly carry out activities for parents and students to participate in the visit experience, special survey, red tourism, volunteer service and social welfare activities to create good family-school relationship and education atmosphere. Third, play the role of parent committee. Kindergartens and primary and middle schools should bring parent committee into the daily management of school, formulate parent committee regulations, and make family education guidance service as the important task. Parent committee invite relevant experts, school principals and relevant teachers, outstanding parents form family education lecturers, organize to carry out varieties of family education guidance services and practical activities. Fourth, do good parental schools together. Local education departments, kindergartens, primary and middle schools cooperate with relevant organizations, and help in team, places, teaching programs and activities. Kindergartens, primary and middle schools should incorporate parental schools into the overall deployment, support parental schools to organize expert teams, design specific family education programs and curriculum, develop family education materials and activity instruction manuals.

(3) Enhance the support of social organizations. First, straighten out the relationship between social organization and government. Government introduces relevant laws and regulations, defines and recognizes rights and obligations of social organization; strengthen the process and dynamic of the social organization management. Establish effective mechanism for supervision and dynamic of social organizations, so the social organization activities run and develop in the sun. Second, enhance the interaction between social organizations and society. Social organizations should pay attention to the development of private enterprises, and cultivate enthusiastic education resources in private enterprises. Attract private enterprises to participate in the project and activities to support family education, let them see the social needs and the results of activities, improve the participation of family education public welfare; social organizations need to strengthen communication and cooperation with the mass media, and make the mass media become an effective platform for advertising and displaying social support activities in family education. Third, innovative forms of social organization support. From the form of social support, professional groups as the guide in public social organizations, large funds as the basis, play guide service and rescue functions in the family education social support. Civil society organizations, are suitable for face-to-face family education guidance, special family education assistance and community family 
education services to meet the family education social support individual and individual needs. Because social organizations have the flexibility and autonomy in management, personnel and activities aspects, we can achieve formal diversity and innovation, build platform and provide resources for social support activities for family education.

(4) Build three-dimensional network support system. In the information age, Internet has become an integral part of people's daily life, the breadth and depth of which in family education has been unprecedented development. Play the advantages of network support system, and develop family education. First, improve the quality of online parental schools. Use online parental schools to narrow the regional differences, rich educational resources, making it a reliable channel for parents to seek family education support. Establish the system of resource sharing between online parental schools. Play the concentrated talent concentration of family education association, and achieve the full use of talent resources. Form dynamic online parental school assessment mechanism. The establishment of online parental schools, we need professional organization assessment. Second, enhance the sense of responsibility of the family education website. Government agency must check the professional competence and service objectives of family education website organizers to protect the legitimate rights and interests of parents. Parents should improve their media accomplishment and enhance the definition of educational information. Third, improve self-discipline ability of we-media users. On the one hand, through education and publicity to guide the blog, WeChat, weibo and other we-media users, improve the aesthetic standards, enhance the sense of responsibility, which make the users consciously send healthy, civilized and useful information to avoid vulgar taste and hearsay; on the other hand, develop scientific and rigorous legal norms, limit the use of the we-media, avoid the dissemination of harmful information, and interfere lives of others.

\section{Conclusion}

Family education is an indispensable education for the healthy growth of children, with the role of school education and social education irreplaceable. With the social progress and the social complicate structure, the importance of family education is more prominent[8]. With the rapid social changes, "family", the most important social unit is facing new challenges, there are worried families with left-behind children in today's society, "hollow" families, single-parent families, family education and subject construction delay, lack of professionals, and there are problems such as excessive education and alienation of education in family education. Family education needs the attention and support from the whole society. Improving the current situation of family education is a long and complex dynamic process, constructing social support system for family education, so that the whole society recognize the important significance of family education on family, society and national development, then urge and promote the government, family, school, common focus on society and solve the problems in family education.

\section{Acknowledgement}

This work is supported by Liaoning educational science project for the 13th Five Year Plan (2016) (JG16EB022): Research on the Construction of Social Support System of Family Education.

\section{References}

[1] F. Wang, "Rural Family Education from the Perspective of Social Support Network -- a Case Study of Rural Family Education in Northern Anhui Province," Journal of Chifeng College (Philosophy and Social Sciences Edition),vol.34, no.5, pp.107-109, 2013

[2] H. Zhang, "The Idea and Strategy of Constructing the Social Support System of Family Education with Chinese Characteristics," China Youth Study, vol. 37, no. 10, pp. 109-113, 2015. 
[3] J.P. Lin, "Research on Social Support System of Family Education," Politics Teaching Reference in Middle School,Vol.36, no.9, pp.72-73, 2015.

[4] S.T. Li, "Research on the Social Support of the Family Education," Dalian: Liaoning Normal University, 2014.

[5] L.P. Chen, "Government and Social Support for Family Education," Legal Daily, 2016-3-6 (7).

[6] Dumbo network, "How to Develop Children's Family Education in the New Media Era," http://mt.sohu.com/20160708/n458422732.shtml, 2016-7-8.

[7] Ministry of Education, "Guiding opinions of the Ministry of education on strengthening family education,"http://www.moe.edu.cn/srcsite/A06/s7053/201510/t20151020_214366.html,2015-1 $0-11$.

[8] B.Z. Yang, "Family Education in the Field of Education," Beijing: Social Science Literature Press, 2003.

[9] Xinbao network, "Yu Minhong proposed the establishment of family education day," http://www.stardaily.com.cn/2017/0306/47936.shtml, 2017-3-6.

[10] J. Nie, L.G. Zhou, Y.M. Li, "A Study on the Problems of Family Education Support for Disadvantaged Groups," Cultural Materials, vol.41, no.4, pp.151-153, 2012. 